be an Algol variable, and a number of the observations made near minima, together with an ephemeris for May, June, and July, are given in the circular.

A plan proposed by Prof. Bailey for the construction of a variable star Durchmusterung, in which the cooperation of amateur and other astronomers is sought, is described in No. 116 of the same publications.

The results of a number of variable-star observations made by Mr. S. D. Townley at the Lick Observatory during the summer of 1902 are published in No. 95 of the Lick Observatory Bulletins. Most of the stars observed were taken from the "Catalogue of Stars recognised as Variable since the Appearance of Chandler's Third Catalogue," which appeared in the Astronomical Journal (vol. xxii.) in 1902 .

\section{VISIT OF REPRESENTATIVES OF FRENCH UNIVERSITY EDUCATION.}

THE French visitors have come and gone. To describe in detail the events of a crowded programme would be impossible. We can here only give a brief sketch. From the first meeting on Whit Monday, at the informal dinner given at the Empress Rooms of the Royal Palace Hotel, it was obvious that the entente between the French savants and their English hosts was sincere and cordial, and that it was of much older standing than the politica agreement. The Vice-Chancellor, Sir Edward Busk, speaking in French, struck the right note at the outset, and Sir Walter Palmer, the chairman of the reception committee, and $\mathrm{Mr}$. P. J. Hartog, the academic registrar of the university (who acted with $\mathrm{Mr}$. W. K. Hill as secretary), both former students of the Sorbonne, welcomed, in the French guests, old teachers and fellow-students.

To the toast of " Our Guests," proposed by Sir Walter Palmer, responses were made by $M$. Bayet (for the Ministry of Public Instruction), M. Boutroux (for the Faculty of Letters of Paris), M. Lippmann (for the Faculty of Sciences of Paris), M. Chavannes (for the Collège de France), M. Thamin and M. Angellier (for the French provincial universities), M. Morel (for the Société des Professeurs de Langues vivantes), and M. Gautier (for the Guilde Internationale), several of whom, including MM. Lippmann and Angellier, spoke in excellent English.

On the following morning the official proceedings began with a reception by Lord Fitzmaurice and $\mathrm{Mr}$. Lough, Parliamentary Secretary of the Board of Education, in the large room of the Foreign Office, followed by luncheon for 300 guests in the East Gallery of the University.

The gallery, which is nearly 200 feet long, was decorated with French and English bunting, and with red, blue, and white flowers; and the French robes of crimson silk (science) and yellow silk (arts), with the ermine-barred epitoga, the scarlet gowns and many-coloured hoods of the Englishmen, and the light summer dresses of the ladies, formed a gorgeous display. It was a surprise to the Frenchmen, who had been somewhat loth to don academic costume, very rarely worn in France, and only on solemn official occasions, to discover its value in a pageant. One of the most distinguished of them prophesied that the English fashion would before long be followed in France.

Official distinction was given to the reception by the presence of M. Cambon, the French Ambassador, who responded to the toast of the President of the French Republic; and the connection of the University with London was emphasised by the toast "Welcome to London" proposed by Mr. Evan Spicer, chairman of the London County Council, and responded to by M. E. Hovelaque, the French Inspector-General, who has of late years transformed the teaching of English in French schools, and who spoke with an ease and distinction that Englishmen might well envy. After lunch came addresses in the Great Hall to an audience of about I 800 persons. The Vice-Chancellor gave a brief but interesting sketch of the relation between the University of Paris and the older English universities; M. Liard, the Vice-Rector of the University of Paris, gave an account of the great and fruitful reforms in French secondary and university education, on which, as Sir Edward Busk justly said, he has for many years exerted "a commanding and beneficent influence"; Sir Arthur Rücker, principal of the University, showed how the ideal of Adam Smith of free and competitive teaching, and the ideal of Dr. Johnson of an endowed and privileged university were united in the University of London with its external and interna sides, and he amused his audience greatly by pointing out that while the test of "residence" at the Inns of Court was eating, and at Oxford and Cambridge was sleeping, that test in London had been divorced a mensâ et thoro Prof. Sadler, as past-president of the Modern Languages Association, a number of the French guests of which were entertained by the University, gave an interesting and suggestive sketch of French influences on English education. After the addresses tea was served in the new, and still unfinished, chemical and physical laboratories of the Royal College of Science, over which the visitors were conducted by Sir Arthur Rücker, Prof. Tilden, Prof Callendar, and the staff of the college. In the evening the guests were invited to meet fellow-specialists informally a parties given by Sir Edward Busk (modern languages and literature), Prof. and Mrs. E. A. Gardner (classics, archæology, and philosophy), Sir William and Lady Ramsay (mathematics and physical sciences), Mr. Mackinder (history and geography), and Dr. Waller, Dr. Farmer, Dr. Halliburton, and Dr. Starling (biological sciences).

On Wednesday morning, June 6 , and afternoon, the County Council took charge of the visitors; they were driven in thirty-five carriages, headed by two mounted policemen, from the Royal Palace Hotel to Westminster, where they inspected the Abbey and school, then to the excellent Camberwell School of Arts and Crafts and the Oliver Goldsmith School, and so to Belair, the beautiful park of Mr. Evan Spicer, where lunch was served in an open marquee. The guests returned via Dulwich College and Picture Gailery, and drove through the Dulwich Common Park, now maintained by the County Council, in which there is a magnificent show of rhododendrons and azaleas. In the evening private dinners were given by the Vice-Chancellor and Lady Busk, the Principal and Lady Rücker, Dr. and Mrs. Bradford, Sir William Collins, M.P., Dr. Headlam, principal of King's College, Mrs. J. R. Green, Sir Philip Magnus, M.P., and Lady Magnus, Dr. and Mrs. T. L. Mears, Sir Walter and Lady Palmer, Dr. and Mrs. Pye-Smith, and the principal, professors, and lecturers of University College.

The evening concluded with a brilliant and crowded reception at the French Embassy.

On Thursday morning, June 7 , a series of eight addresses was given in the Great Hall of the University of a singularly varied and interesting character, in which it may fairly be said that the English speakers, Prof. Gardner, Dean of the Faculty of Arts, who spoke in Latin, Dr. Waller, Dean of the Faculty of Sciences, and Sir William Ramsay, who spoke in French, did not fall short of the high literary level characteristic of French eloquence. M. Croiset and M. Appell, the Deans of the Faculties of Arts and Sciences of Paris, M. Léger, professor at the Collège de France, M. Benoist, Rector of Montpellier, and M. Morel, vice-president of the Société des Professeurs de Langues vivantes, gave addresses on which it is impossible to comment adequately. It is understood that they will be published later, when we hope to have occasion to describe them.

On the afternoon of Thursday, June 7 , the French guests journeyed by special train to Windsor, where they were introduced by Lord Rosebery, Chancellor of the University, and by the Vice-Chancellor, to the King and Queen, and were afterwards entertained at tea in the Castle; and in the evening the proceedings, so far as London was concerned, concluded with a brilliant conversazione at the University.

On June 8 half the guests of the University and of the Modern Language Association were entertained at Oxford and half at Cambridge. The majority left London on Saturday and Sunday, June 9 and Io.

In these festivities there has been much brilliancy, much pomp and circumstance. But behind the show there has been real and solid work accomplished or begun. Lessons are learnt better from men than from books, and the lessons to be derived from French education, to which (with the Army) France has devoted the best part of her energies since $18 \%$, have been sadly neglected by England. We have still to learn that solid secondary education is a NO. I 9 I I. VOL. 74] 
necessary preliminary to fruitful university education; that it is possible to combine literary and scientific training; that both in secondary and in higher teaching, if the teachers are to stimulate individuality in their pupils, they must be given time and opportunity to cultivate and develop their own; that examinations may be used to test the power of taking general views, as well as of remembering an infinity of details; and many other things, which France can teach us. But apart from intellectual profit, there is a moral profit in a meeting of this kind. Blessed are the peace-makers; and the discovery of unsuspected and deep human sympathies between workers in the same intellectual fields, between men and women whose business it is to train up the young minds of their own people, makes for the peace of Europe.

\section{ECONOMIC ENTOMOLOGY. ${ }^{2}$}

(1) SINCE 1867 the State entomologists of Illinois have constantly issued very able reports on noxious and beneficial insects. The first were by Walsh and Le Baron; the last twelve have been by Prof. Forbes, the writer of the present work. In 1894 he issued the first part of " A Monograph of Insect Injuries to Corn." This extended to some I 70 pages, with fifteen plates, and dealt only with those insects that attack the planted seed and the roots of corn of various kinds. This dealt mainly with wire-worm, white-grubs or chafer larvæ, ants, aphis, their natural enemies and means of prevention. The second part that has just appeared is very much better than that issued nearly twelve years ago. It treats of the insect injuries to those parts of the corn plant above ground, including stalk, leaves, and ear.

A very excellent plan we do not remember having seen before is adopted in the text, namely, that of grouping the insects under the following three headings:-(I) the more important pests; (2) the less important pests; and (3) the unimportant species.

In dealing with the first it is pleasing to note that the insects are dealt with in a strictly practical manner. Such reports as these can well be made to serve a double purpose if properly drawn up as this one is, namely, as a reference book for practical men and also for those who are studying the subject from a student's point of view. The coloured plates, of which there are eight, include the army-worm, corn bill-bugs, the chinch bug, the corn-worm, white-grub, the seed-corn maggot, and other well-known corn pests. The plates are good, and show in some cases, not merely the perfect insect, but the whole life-history and the damage produced on the growing plant.

Among the more interesting sections we find a good account of the damage caused by the chinch bug (Blissus leucopterus, Say) and the means of preventing it, of the army-worm (Leucania unipunctata, Haw.), and of the corn-leaf louse (Aphis maidis, Fitch). In regard to the latter some interesting new observations are recorded, although nothing very definite has been arrived at in regard to the life-history of this corn pest. The author (p. 133) refers to " the failure of all attempts to find or produce a bisexual generation or an alternative food plant of Aphis maidis or to learn how and where it passes the winter."

Some interesting notes are given on several species of Crambus, called popularly in the States "sod web-worms" or " root web-worms" (Figs. I and 2). Although we have many species of Crambus in Europe, no very material damage has been recorded. In America we learn that " not infrequently these "web-worms' become so abundant as to cause brown and deadened spots in a lawn or meadow, sometimes, indeed, deadening the turf as thoroughly as white-grubs or cut-worms can do." Corn seems to be very heavily injured and even completely destroyed over considerable areas in early spring. This is

1 (r) "A Monograph of the Insect Injuries to Indian Corn." Part i. By S. A. Forbes. Twenty-third Report of the State Entomologist on the Noxious and Beneficial Insects of the State of Illinois. Pp. 273+xxxiii ; 238 Figures and 8 Coloured Plates. (Chicago, 1905.)

(2) "Departmental Nores on the Insecis that affect Forestry." By E. P. Stebbing, F.L.S., F.Z.S., F.E.S. No. 3, with Preface and Index to vol. i. Pp. $335-469+8$ plates. (Calcutta : Government Printing Office, 1906.) Price $2 s$.

NO. 1911 , VOL. 74$]$ an attack we must be prepared for in many localities in this country when grass land is broken up, an unlikely proceeding, however, at the present day with the low price of corn. Probably a good deal of damage is done here now, but has been attributed to other causes. The figures given by Forbes are thus reproduced to give an idea of the larval stage, during which the damage is done.

In this country, again, we have not observed any injurious Syrphidæ or hover flies, but we find recorded by Forbes (p. I62) that Mesogramma politum, Say, feed, not on Aphides, but on the pollen and juices of corn and cotton (Ashmead). The whole work is full of interesting and sound material alike to the practical man and student. One point we notice; the corn-worm or cotton-worm is still called Heliothis armiger, Hübner, instead of Heliothis obsoleta, Fabricius, which antedates it.

A key to the discussion of insect injuries to corn is given which will prove very usefu to those studying the subject in America, and even elsewhere, for where species differ genera often agree in various parts of the world. A very complete bibliography and a copious index complete the work, which is useful to us in many regions other than

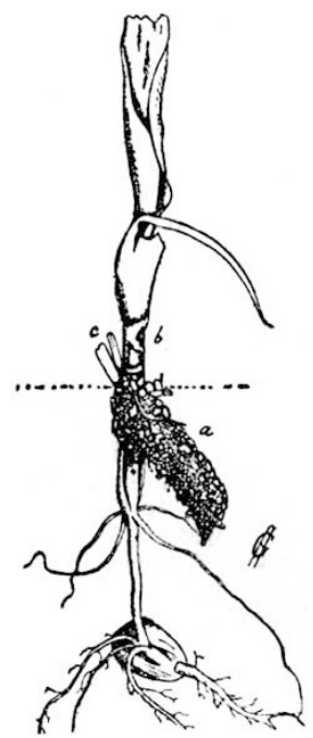

FIG. I.-The Sod Web-worm (Crambus) web (a) containing larva, at base of young leaf and stem.

(2) This work contains a good deal of useful information and a lot of what appear scrappy notes, which will, however, serve a useful purpose later on. The great difficulty of working at such a subject as the one Mr. Stebbing is engaged upon can only be estimated by those who have attempted the like.

The economic entomologist is often too apt to jump at specific and even generic determinations, or is loth to
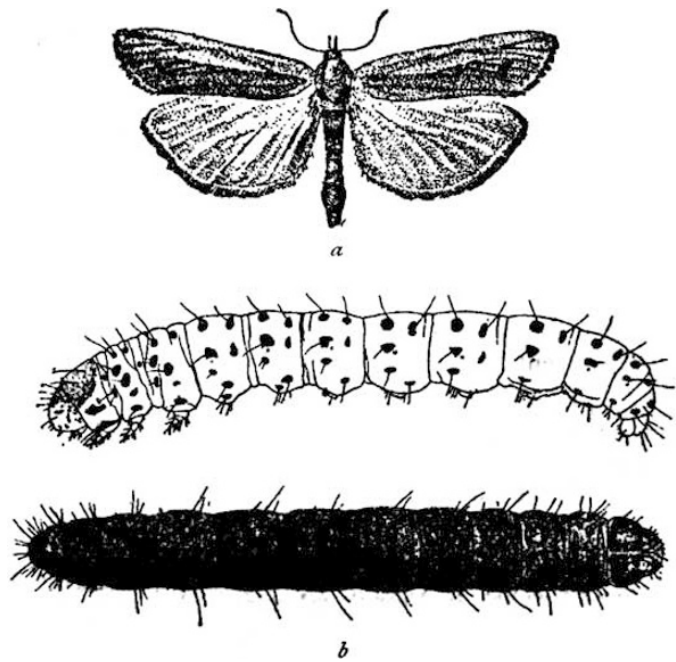

Fig. 2. - The Common Sod Web-worm (Crambus trisectus): $a$, adult slightly enlarged; $b$, back and side views of larva (much enlarged).

publish his observations unless the scientific name can be given. Some groups of insects are almost impossible to name specifically, and many others should only be treated by specialists, who have not always time or inclination to deal with the material sent them. 